\title{
Payments for pioneers? Revisiting the role of external rewards for sustainable innovation under heterogeneous motivations
}

\author{
Aiora ZABALA ${ }^{1 *}$, Unai PASCUAL ${ }^{1,2,3}$, Luis GARCÍA-BARRIOS ${ }^{4}$
}

* Corresponding author: aiora.zabala@gmail.com

${ }^{1}$ Department of Land Economy, University of Cambridge.

19 Silver Street, Cambridge, CB3 9EP, UK.

${ }^{2}$ BC3, Basque Centre for Climate Change.

Edificio Sede $N^{o} 1$, Planta $1^{\mathrm{a}}$, Parque Científico de UPV/EHU

Barrio Sarriena s/n, 48940 Leioa, Bizkaia, Spain

${ }^{3}$ Ikerbasque Basque Foundation for Science.

María Díaz de Haro 3, 48013, Bilbao, SPAIN.

${ }^{4}$ ECOSUR, El Colegio de la Frontera Sur Unidad San Cristóbal.

Carretera Panamericana y Periférico Sur s/n , Barrio María Auxiliadora, CP 29290, San Cristóbal de Las Casas, Chiapas, MEXICO.

Email addresses:

Aiora ZABALA: aiora.zabala@gmail.com

Unai PASCUAL: unai.pascual@bc3research.org

Luis GARCÍA-BARRIOS: 1garcia@ecosur.mx 


\section{Highlights}

- Individuals have diverse, complex motivations to adopt pro-environmental behaviour.

- Acknowledging this heterogeneity is key for cost-effective conservation policies.

- We uncover 3 motivational perspectives for silvopasture adoption in a tropical forest context.

- Payments may not be the most appropriate incentives for pioneers regarding adoption. 


\section{Payments for pioneers? Revisiting the role of external rewards for sustainable innovation under heterogeneous motivations}

\section{Introduction}

When deciding whether to adopt pro-environmental practices, individuals confront trade-offs with multiple other activities in which to invest their resources and effort. In this process of decision-making, the profit maximising rationale is intertwined with other motivational drivers of human behaviour (Calle et al., 2009; Noppers et al., 2014). Even an apparently homogeneous microcosm such as a small rural community in the frontier of a tropical forest is composed of individuals whose behaviour is driven by a high diversity of goals and values (Bathfield et al., 2013). People have diverse ways of interpreting the same phenomena (Bennett, 2016) and, due to heterogeneous motivations, goals and preferences, the response of individuals to the same types of incentives may vary remarkably (Bolderdijk et al., 2012; van der Werff et al., 2013). This motivational diversity can partially explain the unpredictability or ineffectiveness of external interventions $^{1}$ for environment and development (Kline and Wichelns, 1998); it can induce highly variable behavioural responses and, plausibly, undesired outcomes of policy instruments.

Among different policy instruments to favour sustainable productive systems, policies based on economic incentives and market transactions are increasingly being promoted. However, the suitability and the superiority of market-based instruments over other types of incentives is heatedly questioned and contested, particularly when they are aimed at encouraging innovative activities (Kemp and Pontoglio, 2011) such as silvopasture (an agroforestry system that integrates cattle farming). In the case of Payments for Ecosystem Services (PES), key debates refer to their political legitimacy (Corbera and Adger, 2004), long-term effectiveness and efficiency (Muradian et al.,

1 Here we understand the notion of external programs as those designed and implemented by organisations outside of the recipient community. 
2013; Sierra and Russman, 2006; Wunder, 2006), potential interactions with social norms (Villamor and van Noordwijk, 2011), effects such as crowding intrinsic motivations for conservation (D’Adda, 2011; Midler et al., 2015; Narloch et al., 2012), and interwoven efficiency and equity impacts (Corbera and Pascual, 2012; Narloch et al., 2011; Pascual et al., 2014, 2010).

Remarkably, the theory underlying PES relies on an implicit major assumption of rationality associated with utility-maximising behaviour; it is assumed that agents predominantly act upon a simple cost-benefit rationale (Ferraro, 2001; Ferraro and Kiss, 2002). Such characterisation of human beings may be adequate to predict behaviour in contexts involving innovation that is more profitable financially, decisions driven by self-interest, and/or activities predominantly framed in a market economy (Heyman and Ariely, 2004). However, this model may fall short when additional motivations or goals have a considerable role as drivers of behaviour (Edwards-Jones, 2007; Steg et al., 2014). Some examples of such additional motivations are giving higher importance to long-term benefits or to livelihood security, or having a strong social interest relative to self-interest (Gsottbauer and van Den Bergh, 2011).

Much effort and care are put into designing targeting approaches of PES to maximise environmental additionality under constrained program budgets (Alpizar et al., 2015; Wünscher and Engel, 2012). We argue that such a targeting effort may fail if the heterogeneity of participants' motivations towards pro-environmental behaviour is not adequately considered. This is especially the case if PES are to be adaptable to each stage of the diffusion process (Rogers, 1962), particularly for PES to stimulate what motivates early adopters, or so-called pioneers, innovators or visionaries of pro-environmental behaviour (Baumgart-Getz et al., 2012; Egmond et al., 2006). Yet a balance needs to be kept between the precision and the transaction costs of a policy.

While the importance of heterogeneous motivations has been long recognised in environmental policy (Kline and Wichelns, 1998), few studies use information about heterogeneity of motivations in order to explain behavioural decisions and adoption of sustainable agricultural 
innovation (with exceptions such as Blazy et al., 2011; Läpple and Kelley, 2013). This paper uncovers the diversity of motivations that influence active pro-environmental behaviour (as opposed to passive conservation) of smallholders that participate in a programme for sustainable land use through the adoption of silvopasture. The study is contextualised within a voluntary project for fodder tree cultivation in a community in the buffer area of a Biosphere Reserve in the state of Chiapas, in tropical Mexico.

In order to analyse the heterogeneity of perspectives regarding adoption of silvopasture, we use Q methodology, a systematic approach to understand subjective perspectives. Beyond the Q analysis, we also contrast these perspectives with observed data about livelihood strategies and with individuals' short-term adoption within the silvopastoral project. The results shed light on the potential for different forms of external rewards to effectively incentivise those farmers that are more likely to adopt and continue silvopastoral practices. Our analysis of the diverse motivations for pro-environmental behaviour provides important insights for designing adaptive environmental conservation policy that promotes the adoption and continuation of social-ecological innovations.

\section{Case study}

\subsection{Silvopastoral systems and their adoption in the tropics}

Extensive overgrazing, including at small scales, is a threat to soil and forest conservation in the frontier of biodiversity-rich tropical forests (Geist and Lambin, 2001). Deforested land in mountainous areas degrades under strong rainfall in the wet season and compacts under grazing (Valdivieso-Pérez et al., 2012). This degradation affects ecosystem functions (including the system's capability to buffer primary forests) and increases the likelihood of severe perturbations such as floods and landslides (Richter, 2000).

Silvopasture is a type of agroforestry that involves fodder-tree cultivation in pastureland. This approach has a double benefit: it rehabilitates the landscape and provides feed for cattle also during 
dry season, when the lack of pasture in some areas is critical. It is considered an adequate compromise between conservation objectives and livelihoods in social-ecological systems characterised by an important livestock component (Broom, 2013; Murgueitio et al., 2011). Its implementation requires preventing cattle from accessing the trees for a period that ranges between half to a few years, until the trees are strong enough to survive animal browsing.

Many decentralised projects to promote silvopasture have recently been implemented in tropical forest margins to rehabilitate landscapes while promoting sustainable livelihoods. A remarkable initiative has been RISEMP, a multi-site programme carried out by regional research institutions in three Latin American countries, funded by the World Bank and reported in various studies (e.g. Garbach et al., 2012; Montagnini and Finney, 2011; Van Hecken and Bastiaensen, 2010). Pagiola and colleagues $(2008,2007)$ find that the impact of PES in the adoption of silvopasture is complex, one reason being that the effect of PES in such systems may be different depending on recipients' motivations and interests.

Silvopasture has long been a successful management system in a number of traditional agroecosystems (e.g. Iberian dehesas) and it holds much promise for areas in which cattle farming is a more recent phenomena (such as recently colonised tropical forest frontiers). Nevertheless, its diffusion has been slower than envisaged in economic and environmental performance assessments (Cubbage et al., 2012; Gutiérrez et al., 2008), and this lack of adoption has received little attention in the literature.

The literature about factors affecting agroforestry adoption is mostly focused on explicitly measurable farm, household and personal characteristics, amenable to adoption probability analysis (Pattanayak et al., 2003), but not on stakeholders' perspectives. In addition, the literature is scant with regards to silvopasture adoption beyond observable characteristics (with the exception of Calle et al., 2009; Frey et al., 2012; Hayes, 2012). The relationship between cognitive variables and behavioural intention is abundantly addressed in social-psychology theory, yet its empirical 
application to agroforestry adoption and conservation practices in farming is scarce (Lokhorst et al., 2011; McGinty et al., 2008).

\subsection{Encouraging silvopasture in Chiapas}

Chiapas had the largest total loss of forest per year among Mexican states in the 1990s (Céspedes-Flores and Moreno-Sánchez, 2010) and the second largest in the 2000s (Hansen et al., 2013). There is little evidence of a forest transition leading to forest recovery (García-Barrios et al., 2009; Vaca et al., 2012). The reasons for this permanent deforestation are epitomised in the case study explained below.

In the Pacific side of Chiapas, La Sepultura Biosphere Reserve lies on the mountain range that stems from the Andean spine (Figure 1). In the buffer zone of the reserve (the area within the reserve limits but located outside of the core and the outstanding natural area), lower areas and South-oriented slopes are highly deforested. The landscape surrounding human settlements is highly anthropized and faces an increasing risk of soil erosion (Valdivieso-Pérez et al., 2012) due to unsustainable farming practices. Predominant livelihood activities in the buffer area include the production of the traditional Mexican milpa (based on maize and beans), livestock and shade-grown coffee farming, the latter ecologically restricted to only certain areas. 
Figure 1: Location and zonification of La Sepultura Biosphere Reserve in Chiapas, Mexico.

Note: 167,310ha. Sources: CONANP (2006) and INEGI (2012). Made with QGIS (2016).

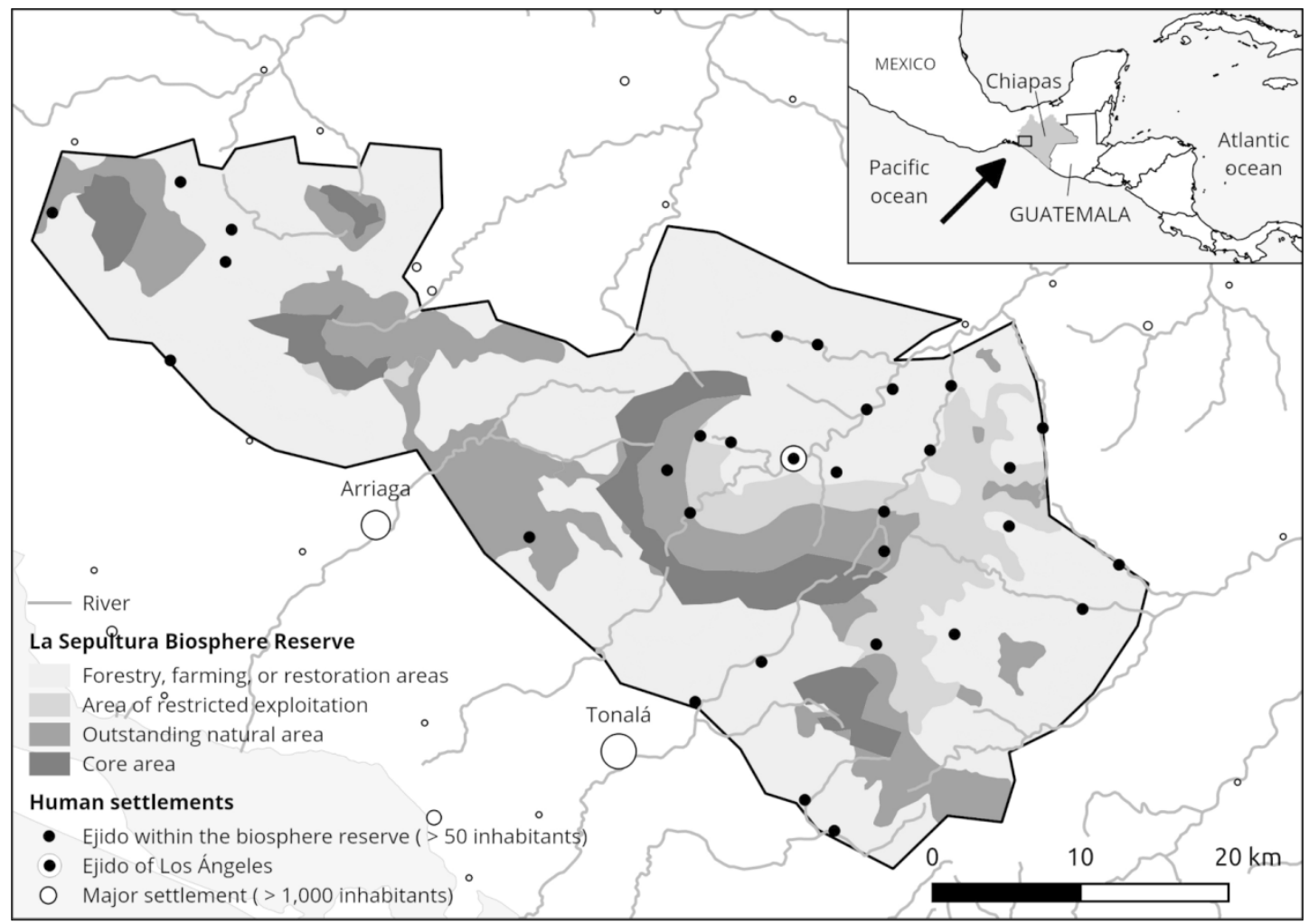
representative one with a population of over 800 people (Trujillo-Vázquez, 2009) distributed in approximately 200 households. The land property regime is a hybrid between the traditional ejido

116 communal lands and customarily recognised private land. Since the community settled down in the

117 1960s, the surrounding forest was progressively cleared for maize first, and converted to cattle

118 farming afterwards (Sanfiorenzo-Barnhard et al., 2009; Valdivieso-Pérez et al., 2012). Following

119 the North American Free Trade Agreement, farming activities began to diversify. With the 120 protection of the area in 1995, farming expansion was restricted. Cattle farming became a preferred 121 livelihood option, mostly limited by financial capital and land ownership. Cattle farming is seen as 122 less risky than cash-crop agriculture because the latter is highly dependent on rainfall and on the 
123 price of chemical inputs. However, this preference is also heavily influenced by variations in

124 international market prices (García-Barrios et al., 2009).

As in the rest of Mexico, households in La Sepultura currently have access to a diverse range of external payments for different purposes, as well as to incentives from various sources in order to

127 promote new sustainable livelihood activities. External PES-like schemes are increasingly viewed 128 by authorities as a cost-effective approach to tackle a range of policy issues (Muñoz-Piña et al., 129 2008). In the case study, many such payment schemes coexist for cattle and agricultural extension, 130 for carbon capture projects, and for hydrological ecosystem services. ${ }^{2}$ Distribution and 131 conditionality for such diversity of payments differ across programmes. Farmers are driven by 132 different motivations to participate in these payment schemes (Shapiro-Garza, 2013).

In Los Ángeles, the research institute El Colegio de la Frontera Sur (ECOSUR) implemented 134 a pilot voluntary and participatory project since 2007 (see García-Barrios, 2012) to encourage cattle 135 farmers to plant native fodder trees in small pasture plots of their own. The project provided 136 incentives in the first year in the form of fencing material and training (Trujillo-Vázquez, 2009). In 137 2008, after a first group of 22 volunteers had planted saplings, the local office of the National 138 Commission of Protected Areas (CONANP) provided additional budget for fencing material for 22 139 more participants, who became part of the group under joint institutional coordination. In 2009, a 140 total of 68 smallholders participated, and CONANP supported these efforts with additional material 141 and cash payments distributed at the group's own criteria (further details are given in Zabala, 2015).

2 The main payment programmes are 'Oportunidades' from SEDESOL (Mexican national secretariat for social development), Procampo (Mexican national programme for direct support to farms) and Progan (Mexican national programme to encourage cattle productivity) from SAGARPA (Mexican department of agriculture, livestock, rural development, fisheries, and food), PESH (Mexican national programme for payments for hydrological services) and Proarbol from CONAFOR (Mexican national commission on forestry), and carbon capture projects by Ambio (Mexican NGO). 
Participants were required to plant the trees in order to receive material and payments, but there was no real conditionality because success in the establishment of fodder trees did not

144 influence the reward received. The actions carried out to cultivate the trees, and the resulting number of trees and their height and quality were monitored for each of the plots (Trujillo-Vázquez, 2009). ${ }^{3}$ The reasons behind the highly variable performance are unclear and scarcely related to age or to the caring activities carried out (Trujillo-Vázquez, 2009).

\section{Q methodology}

$\mathrm{Q}$ is a structured methodology (also known as $\mathrm{Q}$ technique or Q-sort) to explore complex problems in which distinct human perspectives are involved. This exploration is done by identifying different patterns of thought existing within a group on a topic of interest, and this identification needs not be based on a preliminary hypothesis (Brown, 1980; Watts and Stenner, 2012). Patterns of thought are described through a set of statements that represent the whole set of possible opinions around a topic. The statements are given to a purposely selected sample of respondents. Each respondent sorts them on a grid with several columns that typically represent an ordinal scale from most agree to most disagree.

The analysis reduces the responses down to a few perspectives (the factors) that best represent

158 all the views found in the group. These factors are the weighted average response of respondents 159 grouped by similarity (for details, see Zabala, 2014; Zabala and Pascual, 2016). Factors depict the 160 view of an archetypical respondent who would best represent that factor, although they do not 161 necessarily describe any specific real respondent. The view of each respondent will usually be more 162 closely related to one factor than to the rest.

3 In each plot, a median of 62 trees were grown (including saplings that were found about to die), which had a cumulative median height of 8.2m per plot (Trujillo-Vázquez, 2009; Zabala, 2015)囚. 
This methodology is increasingly being used across disciplines, particularly in social-

164 environmental studies and ecological economics, and for different purposes, such as policy

165 evaluation or participatory processes. It is used to identify typologies such as conservationist

166 opinions about market-based instruments (Sandbrook et al., 2013, 2011), farmer environmental

167 perspectives (Davies and Hodge, 2012), opinions about new environmental legislation (Buckley,

168 2012), stakeholder views on energy from biomass (Cuppen et al., 2010), sustainability discourses

169 (Barry and Proops, 1999), perceptions about the uses of forest (Nijnik et al., 2010; Rodríguez-

170 Piñeros and Mayett-Moreno, 2014) and, more recently, on semi-subsistence farmers' motivations to

171 conserve agrobiodiversity (Nordhagen et al., 2017).

\section{$172 \quad 3.1$ Q-set: statements and their structure}

A comprehensive sample of statements was built based on expert consultation, in-depth

174 interviews with four farmers, previous literature, and after extensive fieldwork gathering

175 quantitative and qualitative data on livelihoods, as well as questionnaires about stated preferences

176 on silvopastoral practices conducted on 103 heads of households. The selection of statements

177 follows a hybrid approach by including both naturalistic (directly from respondents'

178 communication) and ready-made statements (expert formulated; McKeown and Thomas, 2013).

179 The initial sample contained 66 statements. $^{4}$

180 The final set of 26 statements (Listed in the Appendices) cover five topics that are most

181 relevant to explain farmers' perspectives with respect to adopting silvopasture, based on literature

182 and on prior fieldwork. These topics are as follows: (A) importance of external payments in

183 livelihoods, (B) environmental and conservation values, (C) personal attitudes towards work and

4 In order to select the statements from the initial sample, the 66 statements were classified into six topics: silvopastoral (14 statements), subsidies/ programmes (16), land/ forest conservation (33), future generations (5), livelihood (30) and cattle (20). The topics were not mutually exclusive. These statements were given a relevance score of $0-3$ by the authors, which aided in the final selection of 26 statements. 
184 livelihoods, (D) beliefs and preferences about cattle farming and land use, and (E) preferences and 185 trade-offs between planting fodder trees and other livelihood activities, including perceptions about 186 potential benefits of fodder trees. ${ }^{5}$

187 The total number of statements was low in comparison with other Q studies in order to ease 188 the sorting process for respondents, some of whom read slowly due to lack of practice. However,

189 the statements selected covered sufficiently the topics explored in this research and provided 190 sufficient variability in the responses, as explained in the results.

\subsection{Respondent selection and administration of $Q$ method surveys}

The statements were designed and administered in Spanish (original versions shown in the Appendices). Everyone in the research team were native speakers. The wording was adapted after

194 pilot testing with experts in the local context and with trusted members of the community, in order to ensure that the statements were concise and clear, and that their meanings did not overlap. in the fodder tree planting project described above and for whom secondary data on involvement and short-term adoption were available (Trujillo-Vázquez, 2009). Respondent selection followed maximum-variability sampling to include a diverse spectrum of smallholders, by using a factorial design based on observed variables. From the 68 individuals who participated in the fodder tree planting project, we shortlisted individuals with highest, lowest and median values of a subset of key variables: cattle specialisation, levels of income, land and livelihood diversity, and level of short-term adoption. All respondents were male, because culturally in this context the male head of household makes and implements decisions over land use. We excluded non participants because

5 Each statement was also classified in three further vectors: attitudes, preferences, perception or trade-offs; whether they refer to the present or the future; and whether they refer to respondents themselves, their descendants, or nonhuman life. 
we were interested in the motivations affecting the level of adoption (i.e. their interest, compromise and effort), not simply in the motivations to participate (i.e. their initial interest). Respondents were interviewed individually face-to-face in August 2010 and January 2011. From those sampled (36), one decided to stop sorting the statements after the survey had started due to fatigue, and three were not available at the time of the survey.

Each respondent divided the statements into three piles of agreement, disagreement and neutral, based on their own views. Next, respondents sorted the statements in a board with a standard pyramidal shape of seven columns representing an ordinal scale (Figure 2). Respondents sorted the statements according to their own agreement: from most agree to most disagree. Finally, respondents briefly explained the reason for sorting the statements in the most extreme positions.

Figure 2: Q methodology distribution for this study

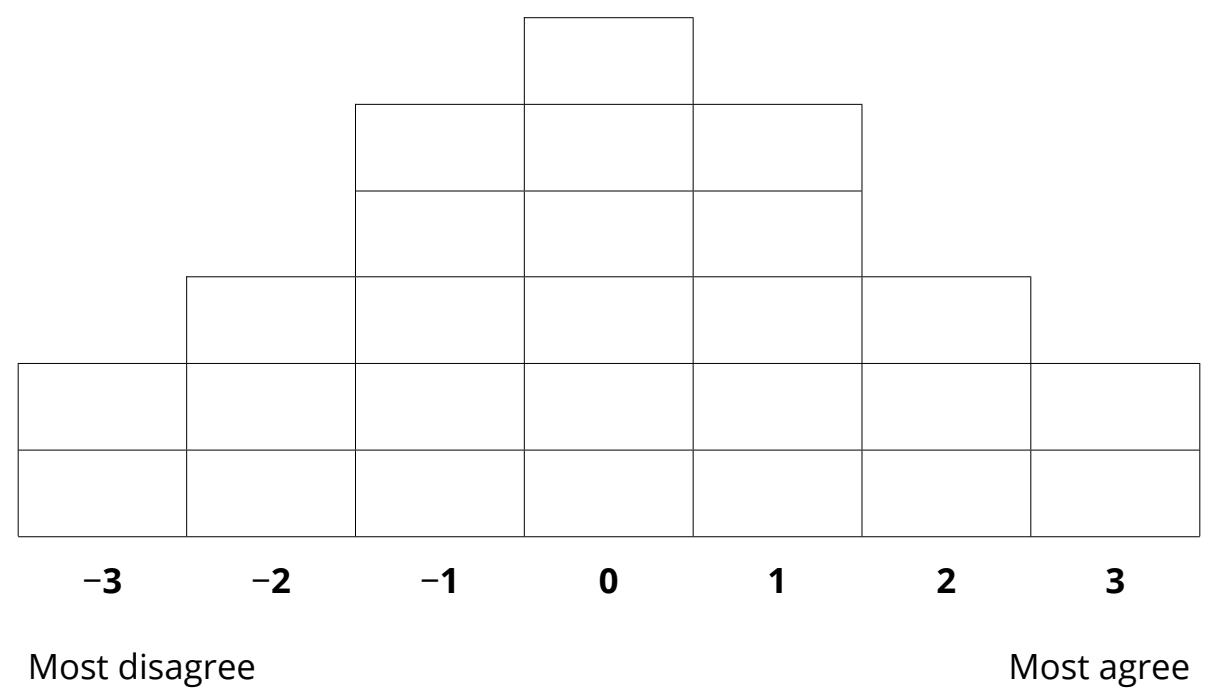

\subsection{Analysis of factors}

The analysis in Q methodology reduces responses to a few main types of perspectives (named

218 'factors' in Q methodology). This is done by means of multivariate analysis, in which respondents are correlated instead of variables (see details in Brown, 1980; Zabala and Pascual, 2016). 
We retained three factors after assessing a number of standard criteria in Q (see e.g. Watts and 221 Stenner, 2012) ${ }^{6}$ and as a parsimonious compromise. Together, the three factors explain $54 \%$ of the variability in the views of respondents, a percentage that is consistent with other Q studies (e.g.

following the standard criteria in Q: those with higher factor loadings in a given factor and with significantly different factor loadings in comparison to other factors. Four respondents were not flagged because they had relatively high loadings in two or three factors, implying that they shared features from more than one view simultaneously.

In addition, we implemented a novel analytic approach of bootstrap re-sampling in Q in order to obtain more precise levels of confidence of the results and to enhance the accuracy of the 230 interpretation (see details in Zabala and Pascual, 2016). The bootstrap approach produces variability 231 (spread) measures specific to the scores of each statement for each factor (standard errors that show 232 their relative stability) and more accurate point estimates. The bootstrap was run in 3,000 steps language (R Core Team, 2016).

6 The first six factors have eigenvalues higher than two and more than one defining respondent, while the first twelve have eigenvalues higher than one. The scree plot indicates that three or four factors would be adequate. The third factor explains $13 \%$ of the variance and the fourth and fifth factors explain $12 \%$ and $10 \%$ respectively. A fourth factor is defined by only three out of the 32 respondents, one of whom defines it in the opposite direction (high negative loading). Importantly, a preliminary interpretation of this fourth factor suggests that the view represented would be very similar to the first factor, with a few traits shared with the second one. We also ran a sensitivity analysis of the final results by selecting from two to eight factors, in order to see whether any of the results changed noticeably in the first few factors. Moderate changes are found in the fourth factor, and significant changes in the fifth and subsequent factors. We also run a sensitivity analysis to identify highly influential respondents. A single highly influential case is found, but we decided not to exclude it from the subsequent analysis. 
236 The analysis yields three main results: the respondents' factor loadings (Appendices), the 237 overall factor characteristics, and the statements' factor and z-scores (Figure 3). The overall 238 characteristics (explained variability and number of defining Q-sorts) indicate that the first factor is 239 highly representative of over a third of the sample and explains a quarter of the total variability in 240 the responses (25\% of the total variability explained, 13 defining Q-sorts). The other two factors 241 also explain a substantial amount of the variability (factor 2, 17\%; factor 3, 13\%), and all factors are 242 represented by a considerable number of defining Q-sorts (factor 2, 8 defining Q-sorts; factor 3, 7). 
PES AND MOTIVATIONS TO ADOPT SILVOPASTURE

Figure 1: Statements selected for Q sorting, bootstrap estimates of their z-scores and distinguishing statements (filled symbols) 


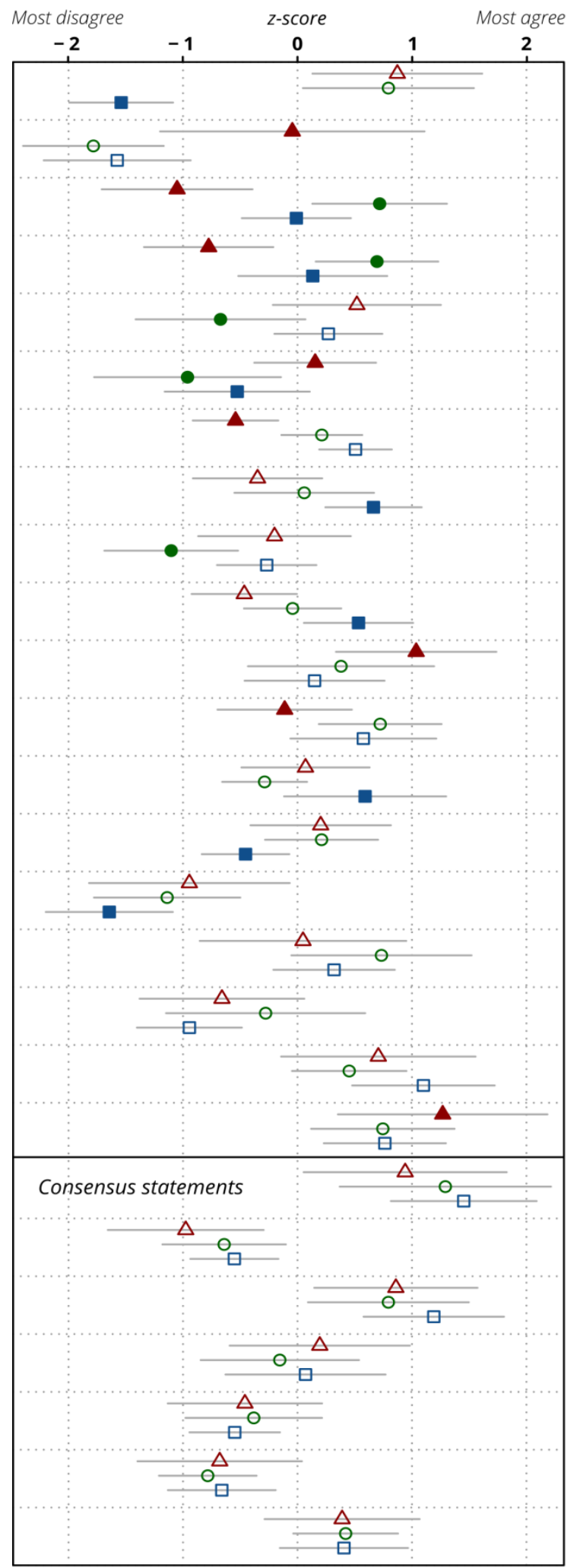

1. Self-sufficient pioneer

- 2. Environmentally-conscious follower

- 3. Payment-dependent conservative

\section{Statement}

15 We need more external payments so that my children do not need to go to live elsewhere.

21 If the government does not give me payments, taking care of the forest does not benefit me.

12 My land is 'getting tired'.

17 If I had more money, I would plant fodder trees instead of increasing my cattle.

6 I could increase my benefits in cattle farming without degrading the land.

18 In dry season there is no alternative other than releasing my cows free into the mountain.

20 It is convenient to weed my fodder tree plot even if I have other tasks, to produce more fodder.

4 I can maintain my family with my own work, external payments are just an aid.

8 I participate in all external programmes that bring income.

22 I try new things in my job.

1 My children and grandchildren will work the same land that I cultivate now.

11 I analyse my costs and benefits and thereafter I work on the most beneficial activity.

2 I prefer two hectares of pasture than one hectare of fodder trees.

13 Benefits from cattle production are larger than loses from its related land degradation.

23 I would rather live by external payments than by working my land.

16 It is more convenient for me to invest money in improving my pastures than in buying cows.

26 In order to dedicate one hectare to fodder trees during two years, I would need more land.

19 With more training I could improve very much my work in cattle farming.

24 I need to improve my pasture, otherwise cattle feed will run out in a few years.

9 It is more convenient for me to cultivate my own food than buying it.

7 Cultivating fodder trees involves a lot of effort and little benefit.

10 Conserving the forest is responsibility of the landowner.

3 The knowledge to earn more is what is of most interest to me from external programmes.

5 With tree planting programmes I receive more money in return for my work.

14 It takes too long for fodder trees to grow.

25 I can earn more as a cattle-farmer if I allow wild animals to live in the forest. 
Note: Ordered from most distinctive (top) to consensus, based on z-score differences. Error bars show the standard error from the bootstrap. Filled symbols indicate that the statement is distinguishing for the given factor.

The statement scores are the main results used for interpretation. The z-scores are the "weighted average of the values that the respondents most closely related to the factor give to a statement" (Zabala \& Pascual 2016). Statement z-scores suggest how the archetypical respondent for each factor would sort the statements. The z-scores are presented here in a novel, synthetic dotchart format (Figure 3). For example, this figure shows that factor 3 disagrees with statement 15 in a distinctive manner in comparison to factors 1 and 2, while it agrees with statement 21 much more than the other factors do.

The interpretation of factors is based on the statement results: their salience within each factor and their distinctive position comparing to that of other factors. Statements that have significantly different scores across factors are distinguishing statements (in Figure 3, statements in which the horizontal distance between markers is large) and they represent an issue of clear disagreement among factors (e.g. statement S12). Statements with the lowest differences in scores across factors are of consensus (markers which are very close to each other; e.g. S25) and indicate common ground and shared understandings of the issue, or otherwise taboos. ${ }^{7}$ As standard in $\mathrm{Q}$, factors are named based on their qualitative interpretation. The justification for these names is given in the last paragraphs of each factor interpretation below.

\subsection{Comparison of factors with observed characteristics}

7 We also analysed the results of statements according to their topic (letters A-D in table of statements in Appendices): calculating the means and standard deviation of z-scores for each topic, in order to see if any one topic was predominant (high absolute averages) or controversial (high deviations) within a given factor, and to compare the responses across factors. This did not yield remarkable insights for this study. 
In addition to the standard Q analysis, the factors are compared with observed characteristics 262 of individuals: key livelihood and socio-economic variables and short-term level of adoption as 263 monitored in the fodder tree planting programme (data from Zabala, 2015 and Trujillo-Vázquez, 264 2009). This comparison has the purpose of describing how these characteristics relate to the factors 265 within the given sample and has descriptive merit rather than inferential, due to the size and 266 purposive nature of the sampling.

267 The comparison was done by means of correlation coefficient tests between the factor 268 loadings - that quantify the similarity of each participant with each factor - and the additional 269 variables. Table 1 shows the correlation test results for these livelihood variables, including 270 specialisation in cattle farming, in other livelihood activities, dependence on external payments, and 271 endowments. ${ }^{8}$

8 In addition, we run ANOVA test for differences among groups according to the level of income (measured in four categories). These tests give no significant results, suggesting that there are no differences in terms of income among the perspectives. 
Table 1: Comparison of factors and key observed variables

\begin{tabular}{lccc}
\hline \multicolumn{1}{c}{ Variable } & $\begin{array}{c}\text { 1. Self- } \\
\text { sufficient }\end{array}$ & $\begin{array}{c}\text { 2. Environmentally- } \\
\text { conscious }\end{array}$ & $\begin{array}{c}\text { 3. Payment- } \\
\text { dependent }\end{array}$ \\
\hline Benefits from cattle farming (\%) & $-0.33^{*}$ & $-0.38^{*}$ & $0.37^{*}$ \\
\hline Benefits from wage labour (\%) & -0.05 & $0.40^{*}$ & -0.24 \\
\hline Benefits from commerce (\%) & 0.08 & 0.08 & $-0.34^{*}$ \\
\hline Benefits from external payments (\%) & 0.06 & -0.06 & 0.09 \\
\hline Livelihood diversity (number of activities) & -0.13 & 0.06 & 0.05 \\
\hline Total land owned (Ha) & -0.17 & $-0.39^{*}$ & 0.26 \\
\hline Experience with cattle farming (years) & $-0.43^{*}$ & -0.23 & $0.46^{*}$ \\
\hline Age & -0.12 & -0.16 & 0.21 \\
\hline Number of youth in the household & $0.38^{*}$ & -0.12 & -0.08 \\
\hline Adoption & 0.24 & 0.23 & -0.18 \\
\hline
\end{tabular}

Number of defining Q-sorts by level of adoption:

\begin{tabular}{rllll}
\hline No plants & 6 & 3 & 6 \\
\hline Some plants & 3 & 4 & 1 \\
\hline Many plants & 4 & 1 & 0 \\
\hline
\end{tabular}

Note: Values correspond to Spearman correlation coefficients between variables and factor loadings for each factor, except for the number of defining Q-sorts by level of adoption. Significance:* $\mathrm{p}<0.1$. Sample $N=32$. For the last variable (level of adoption), counts of individuals defining the factor (flagged) are given.

The level of short-term adoption is defined for this study as the outcomes of growing fodder trees, measured as cumulative height of tree per plot. Adoption was measured one year after the planting of the saplings (Trujillo-Vázquez, 2009) and in the case study is a satisfactory approximation for biomass. This measure was used to categorise farmers into three groups: those with many plants, with some plants, and with none. Table 1 (last three rows) shows the contingency table of defining Q-sorts by the category of short-term adoption in which they fall.

More specialisation in cattle farming distinguishes factor 3 from the rest (in both years of experience and percentage of benefits from cattle). Respondents related to factor 3 appear to have more land, although this is not significant. Dependence on subsidies (external payments) does not significantly distinguish factors, neither does the diversity in livelihood strategies. The comparison 
284 of defining Q-sorts with categories of adoption suggests a pattern: most of those who had many 285 plants are definers of the first factor, and most of those who define the third factor had no plants.

286

\subsection{Interpretation of results}

There is a general consensus that food self-sufficiency is desirable (S9), that conserving the forest is the responsibility of the landowner (S10), and that fodder trees do not take much time and effort to grow (S14). By contrast, major disagreements refer to the importance given to external payments, preferences on cattle farming, and perception about land. Factors 1 and 3 are opposite in their view of external payment schemes (S15, S21). Cattle farming is a topic of remarkable disagreement (topic D in Appendices); there is no consensus with regards to any of the seven statements. The overall perception about land degradation is salient in opposite ways for the second and the third factors (S12). Each factor show distinct preferences towards planting fodder trees (S17, S2, S16): high preference (factor 2), disengagement (factor 1) and low preference (factor 3). Attitudes towards innovation and self-sufficiency are rather distinct for the three factors too (S22).

The following interpretation of the different types of smallholders' perspectives (factors) is structured around three main themes: (i) preferences about investing in increasing the cattle herd, improving pasture, and planting fodder trees; (ii) the reasons why silvopastoral practices are adopted; and (iii) whether such practice would be continued beyond the experimental period.

\subsubsection{The self-sufficient pioneer}

The first factor represents an individual who is pragmatic, self-sufficient, and an innovator. $\mathrm{He}^{9}$ is confident about his capability to maintain his family in an autonomous way and without depending on external financial help (S15, S4, S23). He gives the lowest importance to external

9 The description uses male nouns throughout because all the interviewees were men, as explained in Section 3.2 , and it refers to perspectives held by individuals, rather than by a collective (they). 
payments in comparison to the other two factors, and clearly rejects them as being necessary for the

307 family; PES may not be motivational. He is proactive about learning by experimenting with new 308 practices in order to improve his livelihood (S22), and he considers that he could improve very 309 much his work in cattle farming with further training (S19). He has no clear preference between 310 investing in more cattle or in planting fodder trees, but he would much prefer to invest in better 311 pasture (S2). He thinks it is convenient to take care of the fodder tree plot even though he has other 312 work to do, and does not perceive land availability as a constraint (S20, S26).

The characteristics that would make this person successfully adopt and continue silvopasture 314 are his pro-activeness to experiment with innovative practices, his willingness to learn in order to 315 improve his performance, and his remarkable preference to remain self-sufficient and independent 316 from external payments.

317 This type is identified as a pioneer within a diffusion process, that is, an initial adopter or 318 innovator. This identification is based on his distinctive response to statement S22 and to 319 indications of better performance in the pilot project. Despite not being significantly associated with 320 age, he typically has a young family and fewer years of experience with cattle farming (Table 1). 321 This is a sign of youth and of needing to secure an income in the medium term, and therefore of 322 potentially more receptiveness to innovations.

\subsubsection{The environmentally-conscious follower}

This factor represents an individual that is conservationist, other-regarding, concerned about the future, and a follower in the context of adoption of livelihood innovations. He has the highest degree of environmental awareness and shows concern about soil degradation (S12, S6). He also 327 has a higher preference for fodder trees than the other two factors (S17, S2). He prefers to invest in 328 fodder trees more than in pasture, and remarkably more than in stocking more cattle. For such an 329 individual, the awareness of environmental problems may be an important driver of pro330 environmental behaviour. 
His perception about the importance of external payments is ambiguous. While he shares the self-sufficient pioneer's views on payments (S21), he expresses a clear need for external payments in order for his descendants to eke out a livelihood (S15). This might be due to pessimism about the future, founded on his perception about land being degraded, and presumably about the lack of employment elsewhere.

While this type of farmer is more receptive to PES-like incentives, his actions may be strongly motivated by a higher awareness about the need for environmental conservation (S12).

338 Thus we define this factor as environmentally-conscious. His environmentalist views are supported 339 by the engagement with two further assertions: that the payments provided are not the only reason 340 for participating in external programmes and that, during the dry season, releasing cattle into the 341 forest is not the only alternative (S8, S18). Therefore, this type of farmer may be genuinely more 342 environmentally concerned than the other two, either intrinsically (subsequent to his experience) or 343 because he has internalised the discourse externally introduced by conservation institutions.

344 The environmentally-conscious factor is characterised by having a relatively higher level of 345 income from off-farm activities, possessing less land and deriving a lower share of benefits from 346 external payment schemes (Table 1). He is motivated to conserve land but he does not feel as self347 sufficient and capable as the pioneer. He is also not as proactive in trying new livelihood activities 348 (S22). Thus we interpret this factor also as a follower regarding the adoption of silvopasture.

\subsubsection{The payment-dependent conservative}

The third factor represents an individual that is conservative, payment-dependent, rentseeking, and late adopter or laggard with respect to innovations. He believes that his livelihood is highly dependent on external payments, emphasising most strongly the need for payments in order 353 to live, both for his current livelihood and for his children's future (S15, S4). He emphasises that he 354 may not be able to sustain his family without these payments and would also require PES to take care of the forest (S21). 
He believes that his descendants will work on the same land (S1), and that he will probably not produce enough animal feed if he sticks to current practices (S24). Yet, he does not perceive that his land is currently degrading (S12). He asserts that he can get more benefits from cattle without damaging the land, and that during the dry season he cannot do anything other than release his cattle into the forest (S6, S18). He also has the lowest preference toward fodder trees; his investment preference between pasture and fodder trees is ambiguous (S2), but he clearly prefers direct purchase of cattle than investment in fodder trees (S17). He considers that it is not convenient 363 for him to weed the fodder tree plot (S20), although he acknowledges that planting fodder trees does not involve much effort (S7).

Because he is not keen on trying new practices (S22), this individual is likely to be a late adopter of innovative practices. Because he states high dependence on external payments (which are a form of immediate, easy income) he can be described as rent-seeking, therefore PES may encourage his participation in conservation programmes. However if the payment stops before the practice yields further benefits, he may possibly abandon it (Pagiola et al., 2007). specialisation and with more years of experience in cattle farming (Table 1). They are also associated with a lower share of benefits from off-farm activities.

5 Discussion: reconsidering the role of external rewards in the context of heterogeneous motivations

\subsection{The diversity of motivations for adoption of silvopasture}

The three main perspectives uncovered in the case study are largely consistent with the roles predicted in the theory of diffusion of innovations, according to their general attitude: pioneers, followers and late adopters (Läpple and van Rensburg, 2011; Rogers, 1962). The perspectives are also relatively consistent with other typologies found in the literature on adoption of sustainable 
agricultural practices. Most studies that investigate typologies of potential adopters identify at least one perspective of environmentalists (Brodt et al., 2006; Valdivia et al., 2012), active adopters moved by environmental awareness (Morris and Potter, 1995), or ecosophists (Vartdal 1993 in Padel, 2001). These types are substantially similar to the environmentally-conscious follower identified here. The payment-dependent conservative may be related to previous types such as those characterised by their resistance to adopt (Barnes et al., 2011; Morris and Potter, 1995), production maximisers (Brodt et al., 2006), and passive adopters (Morris and Potter, 1995), who are not moved by conservation concerns.

The first perspective in this study (self-sufficient pioneer) is the most novel one in the socialenvironmental literature, because this type of farmer is a likely adopter of sustainable innovation but is motivated by the potential livelihood benefits that the practice might bring, rather than strictly by environmental reasons. In previous literature, counterparts closest to this perspective are found in categories such as networking entrepreneurs (Brodt et al., 2006) and, roughly, pragmatic organic 393 (Darnhofer et al., 2005).

In addition to the distinction of roles based on diffusion, the $\mathrm{Q}$ results provide a rich 395 description of perspectives in terms of topics relevant to silvopasture adoption and to interventions, 396 particularly the perceptions on incentives and towards conservation. The data suggest that none of 397 the three perspectives has a clearly favourable predisposition to adopt silvopasture. Yet each 398 perspective also has distinct reasons why they might potentially adopt silvopastoral systems. These 399 reasons are the latent motivations that can be stimulated to increase adoption. Finding specific 400 incentives to stimulate these motivations may be instrumental for policy design.

401 The self-sufficient pioneer may adopt only if the practice is believed to be novel and 402 connected with potential broader livelihood improvements, despite the perceived risks. He sees no 403 need for external economic incentives in order to experiment. In contrast, the motivation of the 404 environmentally-conscious follower could be associated with normative or moral concerns driven 
405 by a long-term notion of human-land interactions. The payment-dependent conservative may adopt 406 in a first phase if there is a clear external monetary support involved, or otherwise at a later stage 407 when realising that the early adopters corroborate the economic benefits of the practice. In the case 408 study, it is important to note that the payment-dependent conservative is linked to cattle 409 specialisation; thus those who have arguably a stronger impact over the land are also those less 410 likely to change.

The main characteristics of the self-sufficient pioneers and payment-dependent conservatives

412 are generally consistent with two types of potential adopters identified by Pagiola et al. (2007). 413 These authors indicate that PES are not needed by farmers for whom silvopasture is profitable 414 enough to justify adoption, while for those for whom silvopasture is not profitable at all, adoption 415 happens only while the payment lasts.

416 In sum, the self-sufficient pioneers and the environmentally-conscious followers-who are 417 more receptive to adopt silvopastoral practices - are less motivated by immediate external 418 economic incentives. Likely, they may be highly responsive to other interventions such as sharing 419 information, purporting the benefits of the practice transparently, or facilitating experimentation. 420 These interventions can, for example, raise the self-sufficient pioneers' expectations of benefits, 421 understood in a broad sense, or reduce the perceived risk involved in experimentation.

\subsection{Incentives for social-ecological innovation and potential policy strategies}

Designing PES in a manner that disregards the multiple motivations that drive participants' 424 livelihood decisions may have an unexpected impact on policy performance. For example, the 425 payment-dependent conservative may try the innovative activity attracted by the expectation of 426 income gains in the short term. After the pilot stage, if the viability and the benefits of the 427 sustainable practice are realised, payments may not be necessary for any of these types of 428 individuals; continuation and diffusion of the practice would occur normally. In this case, initial payments would possibly not imply an increase in overall adoption rates but instead a more 
uniform, accelerated adoption process, because more payment-dependent conservatives would participate at earlier stages of the scheme. Instead, if the budget of the external programme is exhausted before the activity is perceived as viable and beneficial, then it is expected that the payment-dependent conservative will discontinue because his main motivation to adopt the practice would disappear (Pagiola et al., 2007). In such a situation, the programme may fail to induce a sustained adoption of the sustainable innovation, probably eroding the permanence of the policy impacts.

Contrary to what much of the literature on PES suggests, voluntary participation in conservation programmes may occur regardless of the uncertain balance between investment and return or of net financial opportunity costs (Kosoy et al., 2007). Payments that cover the opportunity cost might be more correlated with adoption rates in contexts of commoditised market relationships; in these contexts, farmers' profit-maximising rationale translates into their effort being proportional to the economic incentive (Heyman and Ariely, 2004). However, in contexts of wider social exchange and longer term perceptions of human-land interactions, additional motivations may underlie the voluntary adoption of conservation activities, meaning that uptake may not be related to payment levels alone (Heyman and Ariely, 2004; Muradian et al., 2010). More general 446 behavioural motivations include moral or internal motivations and values (Bowles, 2008; Lokhorst 447 et al., 2011; Mzoughi, 2011), such as exploration, looking for innovations, curiosity for 448 experimentation, personal fulfilment, or avoiding becoming an outcast. These are motivational 449 drivers that might go a long way compared to immediate pecuniary returns.

450 Conservation programmes designed to fit an assumed short-term market-transaction mindset 451 and self-interested behaviour can generate a misfit (Brown, 2003) between the design and the 452 recipients' behavioural motivations at the implementation stage (Bowles, 2008). This can potentially 453 result in the erosion of the longer term permanence of the sustainable activity (Muradian et al., 454 2013). It is argued that this misalignment might be due to decisions and behaviour being context- 
455 dependent (Clot et al., 2015). However, environmental psychology also indicates that such 456 behavioural motivations have certain patterns that are not context-dependent and are more complex 457 than those envisaged by rational assumptions (e.g. Osbaldiston and Schott, 2012), as suggested by 458 our empirical data.

A plausible policy strategy could be to target the distribution of incentives, not necessarily payments, to so-called pioneers, who are intrinsically more motivated towards experimentation and for whom a short-term payment is a secondary interest. The type of external incentive to catalyse the pioneers' motivations could be, for example, providing a transparent and convincing informational strategy (Calatrava and Franco, 2011; Egmond et al., 2006) that emphasises the innovative aspect of the new technique and its potential to benefit adopters in social, economic and ecological ways. In turn, this requires providing adequate, clear and comprehensive information about the advantages and disadvantages of the new practice. Reinforcing it through multiple authoritative and trusted sources may reduce the uncertainty involved (Garbach et al., 2012). Further, pioneers may arguably see their motivation spurred if their leading action is socially rewarded (Heyman and Ariely, 2004), for instance by acknowledging their service to the community, or by promoting them as educators or demonstrators in a process of constructive communication with other potential adopters (Atwell and Schulte, 2009; Egmond et al., 2006). distribution of an incentive could be perceived as unfair by the rest and negatively affect the effectiveness of the program as a result (Pascual et al., 2014). Both hurdles may be overcome by designing the intervention with characteristics that implicitly attract mostly the so-called pioneers and with conditions that are not appealing to the payment-dependent, so that pioneers self-select themselves. This design could be realised by providing incentives that specifically tackle needs that 
building or approaches to reduce uncertainty. Later interventions could be based, for example, on catalysing trust between pioneers and followers by enhancing social networks or social influence (Abrahamse and Steg, 2013), or facilitating interaction to encourage the flow of knowledge from early adopters (Baumgart-Getz et al., 2012; Morris et al., 2000). Alternatively, unfairness perceptions might be reduced if the recipients of incentives are selected through applications to demonstrate suitability, as if it were a selection for a job position (Knight et al., 2010). ${ }^{10}$

Targeting may also be achieved by designing a dynamic and adaptive program. For example, in a first phase, no information would be provided about prospective payments or other similar incentives, but rather about proven potential benefits of the practice, so that mostly pioneers would volunteer to participate. In a second phase, small payments might be introduced to attract new participants among those who are potentially followers but are undecided. In a third phase, when the benefits of the activity begin to realise and both pioneers and followers have already adopted the new practice, further payments might be necessary to accelerate the participation of late adopters. This dynamic approach that adapts incentives in stages in order to match diffusion roles complements the recognised need for adaptability and flexibility of PES (Pascual et al., 2014).

\section{Conclusions}

In order to be flexible and adaptive, incentive-based policy instruments such as PES require $a$ priori understanding of the key underlying behavioural motivations of individuals who participate in conservation initiatives. However, to date there is a paucity of empirical research that can serve as a model for cost-effective identification of the heterogeneity of such motivations.

In this paper we uncover the heterogeneity of motivations among participants in a PES-like project to encourage sustainable silvopastoral practices in a tropical forest frontier in Mexico. We

10 The idea of calls for applications was put forward by Knight in a presentation of the fieldwork used for the study cited. 
have connected the theory of incentive-based conservation programmes to promote the diffusion of pro-environmental behaviour, with a case of a scheme to encourage silvopastoral adoption in a small community in Chiapas. We provide empirical evidence about the importance of understanding the attitudinal fabric of a small and otherwise seemingly homogeneous community. Our study provides further evidence to support that applying Q methodology facilitates the exploration of diverse viewpoints and motivations for the adoption of sustainable practices in a wide range of socio-cultural contexts (e.g. Nordhagen et al., 2017). Ascertaining such motivations can help identify pioneers in a diffusion process, who can play a key role as catalysts for the adoption of innovative practices.

Our findings contribute to acknowledging the importance of careful design of PES schemes where people's motivations are likely to be heterogeneous. We find evidence to support that PES design needs to discourage rent-seeking strategies driven by short-term financial benefits (Kronenberg and Hubacek, 2013). We argue that uncovering the latent diversity of motivations for adoption of sustainable practices is key for the cost-effective design of PES schemes and to avoid rent-seeking strategies that could undermine their effectiveness in the medium to long term. Analysing the motivations of non-participants and of individuals in other locations with potential for implementing silvopastoral systems may inform further how to best encourage adoption of such practices.

Based on our findings from Chiapas in the context of the silvopastoral adoption program, we derive two general implications for the design of voluntary payment schemes such as PES. First, a higher cost-effectiveness and a more permanent behavioural change toward adoption of the environmental innovation can be achieved by designing conservation programmes in a way that they deactivate or minimise rent-seeking strategies, which are the ones most likely to discontinue 
the activity once the budget supporting the programme ceases. ${ }^{11}$ Second, a stronger emphasis on engaging so-called self-sufficient pioneers from the outset may also enhance cost-effectiveness.

Accordingly, PES-like schemes may be designed in a way that they implicitly attract individuals genuinely interested in the conservation activity first (which may also include so-called environmentally-conscious followers). These individuals are more likely to strive for successful environmental performance and may have a boosting effect in getting the rest to adopt, when the demonstration of the private benefits from the activity is sufficient to motivate others. The selfsufficient pioneers may be encouraged by catalysing their latent motivations to adopt the proenvironmental practice. It has to be taken into account though, that for this type of individual

534 financial stimuli may not be the most appropriate incentive and can be insufficient (Läpple and 535 Kelley, 2013) or even counterproductive to foster adoption and continuation in the longer term, due 536 to the potential to crowd-out intrinsic motivations (Bowles, 2008; Midler et al., 2015). drivers of these actors are homogeneous (due to their similar socio-cultural and economic 540 background) blinds us from the richness of their motivations. Any policy intervention in such 541 contexts must account for the diversity of behavioural motivations, otherwise it is likely that its 542 effects may be minimal if not counterproductive to the original goals.

11 The continuation of pro-environmental behaviour after a payment-based intervention has been questioned in the literature, and some evidence has been provided (Reutemann et al., 2016). However, further empirical research is needed to understand the long-term impact. 
544 AZ is grateful to the Basque Government for funding this research (AK2009). Fieldwork was 545 partially funded by Consejo Nacional de Ciencia y Tecnología, CONACYT project 51293 (Studies 546 on SocioEnvironmental Complexity) and FORDECYT project 116306 (Social-Environmental 547 Innovation in the Southern Frontier, Mexico). The authors are grateful to Romeo Trujillo-Vázquez 548 for his invaluable support, and to Amayrani Meza-Jiménez for helping with Q administration. 
PES AND MOTIVATIONS TO ADOPT SILVOPASTURE

\section{References}


Abrahamse, W., Steg, L., 2013. Social influence approaches to encourage resource conservation: A meta-analysis. Glob. Environ. Chang. 23, 1773-1785. doi:10.1016/j.gloenvcha.2013.07.029

Alpizar, F., Norden, A., Pfaff, A., Robalino, J., 2015. Unintended Effects of Targeting an Environmental Rebate. Environ. Resour. Econ. 1-22. doi:10.1007/s10640-015-9981-2

Atwell, R., Schulte, L., 2009. Linking resilience theory and diffusion of innovations theory to understand the potential for perennials in the US Corn Belt. Ecol. Soc. 14, 30.

Barnes, A., Willock, J., Toma, L., Hall, C., 2011. Utilising a farmer typology to understand farmer behaviour towards water quality management: Nitrate Vulnerable Zones in Scotland. J. Environ. Plan. Manag. 54, 477-494.

Barry, J., Proops, J., 1999. Seeking sustainability discourses with Q methodology. Ecol. Econ. 28, 337-345. doi:10.1016/S0921-8009(98)00053-6

Bathfield, B., Gasselin, P., López-Ridaura, S., Vandame, R., 2013. A flexibility framework to understand the adaptation of small coffee and honey producers facing market shocks. Geogr. J. 179, 356-368. doi:10.1111/geoj.12004

Baumgart-Getz, A., Prokopy, L.S., Floress, K., 2012. Why farmers adopt best management practice in the United States: a meta-analysis of the adoption literature. J. Environ. Manage. 96, 17-25. doi:10.1016/j.jenvman.2011.10.006

Bennett, N.J., 2016. Using perceptions as evidence to improve conservation and environmental management. Conserv. Biol. doi:10.1111/cobi.12681

Blazy, J.-M., Carpentier, A., Thomas, A., 2011. The willingness to adopt agro-ecological innovations: Application of choice modelling to Caribbean banana planters. Ecol. Econ. 72, 140-150. doi:10.1016/j.ecolecon.2011.09.021

Bolderdijk, J.W., Steg, L., Geller, E.S., Lehman, P.K., Postmes, T., 2012. Comparing the effectiveness of monetary versus moral motives in environmental campaigning. Nat. Clim. Chang. 3, 413-416. doi:10.1038/nclimate1767

Bowles, S., 2008. Policies designed for self-interested citizens may undermine "the moral sentiments": evidence from economic experiments. Science (80-. ). 320, 1605-9. doi:10.1126/science. 1152110

Brodt, S., Klonsky, K., Tourte, L., 2006. Farmer goals and management styles: Implications for advancing biologically based agriculture. Agric. Syst. 89, 90-105. doi:10.1016/j.agsy.2005.08.005

Broom, D., 2013. Sustainable, efficient livestock production with high biodiversity and good welfare for animals. Proc. R. Soc. B 280.

Brown, K., 2003. Integrating conservation and development: a case of institutional misfit. Front. Ecol. Environ. 1, 479-487. 
585

586

587

588

589

590

591

592

593

594

595

596

597

598

599

600

601

602

603

604

605

606

607

608

609

610

611

612

613

614

615

616

617

618

619

Brown, S.R., 1980. Political subjectivity: Applications of Q methodology in political science. Yale University Press, New Haven and London. Available at http://qmethod.org/papers/Brown1980-PoliticalSubjectivity.pdf.

Buckley, C., 2012. Implementation of the EU Nitrates Directive in the Republic of Ireland - A view from the farm. Ecol. Econ. 78, 29-36. doi:10.1016/j.ecolecon.2012.02.031

Calatrava, J., Franco, J.A., 2011. Using pruning residues as mulch: analysis of its adoption and process of diffusion in Southern Spain olive orchards. J. Environ. Manage. 92, 620-9. doi:10.1016/j.jenvman.2010.09.023

Calle, A., Montagnini, F., Zuluaga, A., 2009. Farmer's perceptions of silvopastoral system promotion in Quindío, Colombia. Bois forêts des Trop. 79-94.

Céspedes-Flores, S.E., Moreno-Sánchez, E., 2010. Estimación del valor de la pérdida de recurso forestal y su relación con la reforestación en las entidades federativas de México. Investig. Ambient. Cienc. y política pública 2, 5-13.

Clot, S., Andriamahefazafy, F., Grolleau, G., Ibanez, L., Méral, P., 2015. Compensation and Rewards for Environmental Services (CRES) and efficient design of contracts in developing countries . Behavioral insights from a natural field experiment. Ecol. Econ. 113, 85-96. doi:10.1016/j.ecolecon.2015.02.021

CONANP, 2006. Zonificación de la Reserva de la Biosfera La Sepultura de acuerdo a su Programa de Manejo.

Corbera, E., Adger, W.N., 2004. The equity and legitimacy of markets for ecosystem services: Carbon forestry activities in Chiapas, Mexico, in: International Association for the Study of Common Property Conference. pp. 1-23.

Corbera, E., Pascual, U., 2012. Ecosystem services: heed social goals. Science 335(6069), 655-656.

Cubbage, F., Balmelli, G., Bussoni, A., Noellemeyer, E., Pachas, A.N., Fassola, H., Colcombet, L., Rossner, B., Frey, G.E., Dube, F., Silva, M.L., Stevenson, H., Hamilton, J., Hubbard, W., 2012. Comparing silvopastoral systems and prospects in eight regions of the world. Agrofor. Syst. 86, 303-314. doi:10.1007/s10457-012-9482-z

Cuppen, E., Breukers, S., Hisschemöller, M., Bergsma, E., 2010. Q methodology to select participants for a stakeholder dialogue on energy options from biomass in the Netherlands. Ecol. Econ. 69, 579-591. doi:10.1016/j.ecolecon.2009.09.005

D'Adda, G., 2011. Motivation crowding in environmental protection: Evidence from an artefactual field experiment. Ecol. Econ. 70, 2083-2097. doi:10.1016/j.ecolecon.2011.06.006

Darnhofer, I., Schneeberger, W., Freyer, B., 2005. Converting or not converting to organic farming in Austria: Farmer types and their rationale. Agric. Human Values 22, 39-52. doi:10.1007/s10460-004-7229-9 
Davies, B.B., Hodge, I.D., 2012. Shifting environmental perspectives in agriculture: Repeated Q analysis and the stability of preference structures. Ecol. Econ. 83, 51-57. doi:10.1016/j.ecolecon.2012.08.013

Edwards-Jones, G., 2007. Modelling farmer decision-making: concepts, progress and challenges. Anim. Sci. 82, 783-790. doi:10.1017/ASC2006112

Egmond, C., Jonkers, R., Kok, G., 2006. One size fits all? Policy instruments should fit the segments of target groups. Energy Policy 34, 3464-3474. doi:10.1016/j.enpol.2005.07.017

Ferraro, P.J., 2001. Global Habitat Protection: Limitations of Development Interventions and a Role for Conservation Performance Payments. Conserv. Biol. 15, 990-1000.

Ferraro, P.J., Kiss, A., 2002. Direct payments to conserve biodiversity. Science (80-. ). 298, 17181719 .

Frey, G.E., Fassola, H.E., Pachas, a. N., Colcombet, L., Lacorte, S.M., Pérez, O., Renkow, M., Warren, S.T., Cubbage, F.W., 2012. Perceptions of silvopasture systems among adopters in northeast Argentina. Agric. Syst. 105, 21-32. doi:10.1016/j.agsy.2011.09.001

Garbach, K., Lubell, M., DeClerck, F. a. J., 2012. Payment for Ecosystem Services: The roles of positive incentives and information sharing in stimulating adoption of silvopastoral conservation practices. Agric. Ecosyst. Environ. 156, 27-36. doi:10.1016/j.agee.2012.04.017

García-Barrios, L.E., 2012. Innovación socioambiental en la cuenca alta del río El Tablón (CART), Sierra de Villaflores, Chiapas. Objetivo, estrategia y métodos de investigación-acción participativa, in: Bello-Baltazar, E., Naranjo-Piñera, E., Vandame, R. (Eds.), La Otra Innovación Para El Ambiente Y La Sociedad En La Frontera Sur de México. Red de Espacios de Innovación Socioambiental, REDISA, pp. 145-170.

García-Barrios, L.E., Waterman, A., Garcia-Barrios, R., Brunel, M.-C., Cruz-Morales, J., 2009. Sierra Springs: A generic table-top game addressing conflict and cooperation between stakeholders involved in managing land, forest and water in a subhumid tropical mountain watershed, in: International Simulation and Gaming Conference.

Geist, H.J., Lambin, E.F., 2001. What drives tropical deforestation? (No. 4), LUCC Report Series. Louvain-la-Neuve.

Gsottbauer, E., van Den Bergh, J.C.J.M., 2011. Environmental policy theory given bounded rationality and other-regarding preferences. Environ. Resour. Econ. 49, 263-304. doi:10.1007/s10640-010-9433-y

Gutiérrez, Z., Viera, G., Fraga, J., 2008. Environmental Impact Assessment of the Establishment of Silvopastoral Systems in San Pedro River Basin, Camagüey, Cuba. Zootec. Trop. 26, 175-178.

Hansen, M.C., Potapov, P. V, Moore, R., Hancher, M., Turubanova, S. a, Tyukavina, A., Thau, D., Stehman, S. V, Goetz, S.J., Loveland, T.R., Kommareddy, A., Egorov, A., Chini, L., Justice, C.O., Townshend, J.R.G., 2013. High-resolution global maps of 21st-century forest cover change. Science (80-. ). 342, 850-3. doi:10.1126/science.1244693 
Hayes, T.M., 2012. Payment for ecosystem services, sustained behavioural change, and adaptive management: peasant perspectives in the Colombian Andes. Environ. Conserv. 39, 144-153. doi:10.1017/S0376892912000045

Heyman, J., Ariely, D., 2004. Effort for payment: A tale of two markets. Psychol. Sci. 15, 787-793.

INEGI, 2012. Localidades de la República Mexicana, 2010.

Kemp, R., Pontoglio, S., 2011. The innovation effects of environmental policy instruments - A typical case of the blind men and the elephant? Ecol. Econ. 72, 28-36. doi:10.1016/j.ecolecon.2011.09.014

Kline, J., Wichelns, D., 1998. Measuring heterogeneous preferences for preserving farmland and open space. Ecol. Econ. 26, 211-224. doi:10.1016/S0921-8009(97)00115-8

Knight, A.T., Cowling, R.M., Difford, M., Campbell, B.M., 2010. Mapping human and social dimensions of conservation opportunity for the scheduling of conservation action on private land. Conserv. Biol. 24, 1348-58. doi:10.1111/j.1523-1739.2010.01494.x

Kosoy, N., Martinez-Tuna, M., Muradian, R., Martinez-Alier, J., 2007. Payments for environmental services in watersheds: Insights from a comparative study of three cases in Central America. Ecol. Econ. 61, 446-455. doi:10.1016/j.ecolecon.2006.03.016

Kronenberg, J., Hubacek, K., 2013. Ecology and Society: Could Payments for Ecosystem Services Create an "Ecosystem Service Curse"? Ecol. Soc. 18. doi:http://dx.doi.org/10.5751/ES-05240180110

Lansing, D.M., 2013. Not all baselines are created equal: A Q methodology analysis of stakeholder perspectives of additionality in a carbon forestry offset project in Costa Rica. Glob. Environ. Chang. 23, 654-663. doi:10.1016/j.gloenvcha.2013.02.005

Läpple, D., Kelley, H., 2013. Understanding the uptake of organic farming: Accounting for heterogeneities among Irish farmers. Ecol. Econ. 88, 11-19. doi:10.1016/j.ecolecon.2012.12.025

Läpple, D., van Rensburg, T., 2011. Adoption of organic farming: Are there differences between early and late adoption? Ecol. Econ. 70, 1406-1414. doi:10.1016/j.ecolecon.2011.03.002

Lokhorst, A.M., Staats, H., van Dijk, J., van Dijk, E., de Snoo, G., 2011. What's in it for Me? Motivational Differences between Farmers' Subsidised and Non-Subsidised Conservation Practices. Appl. Psychol. An Int. Rev. 60, 337-353. doi:10.1111/j.1464-0597.2011.00438.x

McGinty, M.M., Swisher, M.E., Alavalapati, J.R.R., 2008. Agroforestry adoption and maintenance: self-efficacy, attitudes and socio-economic factors. Agrofor. Syst. 73, 99-108. doi:10.1007/s 10457-008-9114-9

McKeown, B., Thomas, D., 2013. Q-Methodology. Sage Publications, London. 
Midler, E., Pascual, U., Drucker, A.G., Narloch, U., Soto, J.L., 2015. Unraveling the effects of payments for ecosystem services on motivations for collective action. Ecol. Econ. 120, 394405. doi:10.1016/j.ecolecon.2015.04.006

Montagnini, F., Finney, C., 2011. Payments for Environmental Services in Latin America as a Tool for Restoration and Rural Development. AMBIO A J. Hum. Environ. 40, 1-13. doi:10.1007/s13280-010-0114-4

Morris, C., Potter, C., 1995. Recruiting the new conservationists: Farmers' adoption of agrienvironmental schemes in the U.K. J. Rural Stud. 11, 51-63. doi:10.1016/07430167(94)00037-A

Morris, J., Mills, J., Crawford, I.M., 2000. Promoting farmer uptake of agri-environment schemes: the Countryside Stewardship Arable Options Scheme. Land use policy 17, 241-254. doi:10.1016/S0264-8377(00)00021-1

Muñoz-Piña, C., Guevara, A., Torres, J.M., Braña, J., 2008. Paying for the hydrological services of Mexico's forests: Analysis, negotiations and results. Ecol. Econ. 65, 725-736. doi:10.1016/j.ecolecon.2007.07.031

Muradian, R., Arsel, M., Pellegrini, L., Adaman, F., Aguilar, B., Agarwal, B., Corbera, E., Ezzine de Blas, D., Farley, J., Froger, G., Garcia-Frapolli, E., Gómez-Baggethun, E., Gowdy, J., Kosoy, N., Le Coq, J.F., Leroy, P., May, P., Méral, P., Mibielli, P., Norgaard, R., Ozkaynak, B., Pascual, U., Pengue, W., Perez, M., Pesche, D., Pirard, R., Ramos-Martin, J., Rival, L., Saenz, F., Van Hecken, G., Vatn, A., Vira, B., Urama, K., 2013. Payments for ecosystem services and the fatal attraction of win-win solutions. Conserv. Lett. 6, 274-279. doi:10.1111/j.1755-263X.2012.00309.x

Muradian, R., Corbera, E., Pascual, U., Kosoy, N., May, P.H., 2010. Reconciling theory and practice: An alternative conceptual framework for understanding payments for environmental services. Ecol. Econ. 69, 1202-1208. doi:10.1016/j.ecolecon.2009.11.006

Murgueitio, E., Calle, Z., Uribe, F., Calle, A., Solorio, B., 2011. Native trees and shrubs for the productive rehabilitation of tropical cattle ranching lands. For. Ecol. Manage. 261, 1654-1663. doi:10.1016/j.foreco.2010.09.027

Mzoughi, N., 2011. Farmers adoption of integrated crop protection and organic farming: Do moral and social concerns matter? Ecol. Econ. 70, 1536-1545. doi:10.1016/j.ecolecon.2011.03.016

Narloch, U., Pascual, U., Drucker, A.G., 2012. Collective Action Dynamics under External Rewards: Experimental Insights from Andean Farming Communities. World Dev. 40, 20962107. doi:10.1016/j.worlddev.2012.03.014

Narloch, U., Pascual, U., Drucker, A.G., 2011. Cost-effectiveness targeting under multiple conservation goals and equity considerations in the Andes. Environ. Conserv. 38, 417-425. doi:10.1017/S0376892911000397 
Nijnik, M., Nijnik, A., Lundin, L., Staszewski, T., Postolache, C., 2010. A study of stakeholders' perspectives on multi-functional forests in Europe. For. Trees Livelihoods 19, 341-358. doi:10.1080/14728028.2010.9752677

Noppers, E.H., Keizer, K., Bolderdijk, J.W., Steg, L., 2014. The adoption of sustainable innovations: Driven by symbolic and environmental motives. Glob. Environ. Chang. 25, 5262. doi:10.1016/j.gloenvcha.2014.01.012

Nordhagen, S., Pascual, U., Drucker, A.G., 2017. Feeding the household, growing the business, or just showing off? Farmers' motivations for crop diversity choices in Papua New Guineas. Ecol. Econ.

Osbaldiston, R., Schott, J.P., 2012. Environmental Sustainability and Behavioral Science: MetaAnalysis of Proenvironmental Behavior Experiments. Environ. Behav. 44, 257-299. doi:10.1177/0013916511402673

Padel, S., 2001. Conversion to organic farming: a typical example of the diffusion of an innovation? Sociol. Ruralis 41, 40-61. doi:10.1111/1467-9523.00169

Pagiola, S., Ramirez, E., Gobbi, J., Dehaan, C., Ibrahim, M., Murgueitio, E., Ruiz, J., 2007. Paying for the environmental services of silvopastoral practices in Nicaragua. Ecol. Econ. 64, 374385. doi:10.1016/j.ecolecon.2007.04.014

Pagiola, S., Rios, A.R., Arcenas, A., 2008. Can the poor participate in payments for environmental services? Lessons from the Silvopastoral Project in Nicaragua. Environ. Dev. Econ. 13, 299325. doi:10.1017/S1355770X08004270

Pascual, U., Muradian, R., Rodriguez, L.C., Duraiappah, A., 2010. Exploring the links between equity and efficiency in payments for environmental services: A conceptual approach. Ecol. Econ. 69, 1237-1244. doi:10.1016/j.ecolecon.2009.11.004

Pascual, U., Phelps, J., Garmendia, E., Brown, K., Corbera, E., Martin, A., Gómez-Baggethun, E., Muradian, R., 2014. Social Equity Matters in Payments for Ecosystem Services. Bioscience 64, 1027-1036. doi:10.1093/biosci/biu146

Pattanayak, S., Mercer, D.E., Sills, E., Yang, J., 2003. Taking stock of agroforestry adoption studies. Agrofor. Syst. 57, 173-186. doi:10.1200/JCO.2003.11.022

QGIS Development Team, 2016. QGIS Geographic Information System.

R Core Team, 2016. R: A language and environment for statistical computing.

Reutemann, T., Engel, S., Pareja, E., 2016. How (not) to pay: Field experimental evidence on the design of REDD+ payments. Ecol. Econ. 129, 220-229. doi:10.1016/j.ecolecon.2016.05.020

Richter, M., 2000. The ecological crisis in Chiapas: a case study from Central America. Mt. Res. Dev. 20, 332-339. 
Rodríguez-Piñeros, S., Mayett-Moreno, Y., 2014. Forest owners' perceptions of ecotourism: Integrating community values and forest conservation. Ambio 99-109. doi:10.1007/s13280014-0544-5

Rogers, E.M., 1962. Diffusion of innovations. Free Press, New York.

Sandbrook, C.G., Fisher, J.A., Vira, B., 2013. What do conservationists think about markets? Geoforum 50, 232-240. doi:10.1016/j.geoforum.2013.09.009

Sandbrook, C.G., Scales, I.R., Vira, B., Adams, W.M., 2011. Value plurality among conservation professionals. Conserv. Biol. 25, 285-94. doi:10.1111/j.1523-1739.2010.01592.x

Sanfiorenzo-Barnhard, C., García-Barrios, L.E., Meléndez-Ackerman, E., Trujillo-Vázquez, R., 2009. Woody Cover and Local Farmers' Perceptions of Active Pasturelands in La Sepultura Biosphere Reserve Buffer Zone, Mexico. Mt. Res. Dev. 29, 320-327. doi:10.1659/mrd.00013

Shapiro-Garza, E., 2013. Contesting the market-based nature of Mexico's national payments for ecosystem services programs: Four sites of articulation and hybridization. Geoforum 46, 5-15. doi:10.1016/j.geoforum.2012.11.018

Sierra, R., Russman, E., 2006. On the efficiency of environmental service payments: A forest conservation assessment in the Osa Peninsula, Costa Rica. Ecol. Econ. 59, 131-141. doi:doi:10.1016/ j.ecolecon.2005. 10.010

Steg, L., Bolderdijk, J.W., Keizer, K., Perlaviciute, G., 2014. An Integrated Framework for Encouraging Pro-environmental Behaviour: The role of values, situational factors and goals. J. Environ. Psychol. 38, 104-115. doi:10.1016/j.jenvp.2014.01.002

Trujillo-Vázquez, R., 2009. Viabilidad Ecológica y Social del establecimiento de módulos silvopastoriles en el Ejido Los Ángeles, Zona de Amortiguamiento de la Reserva de la Biósfera La Sepultura, Chiapas, México. Universidad Internacional de Andalucia.

Vaca, R.A., Golicher, D.J., Cayuela, L., Hewson, J., Steininger, M., 2012. Evidence of incipient forest transition in Southern Mexico. PLoS One 7, e42309. doi:10.1371/journal.pone.0042309

Valdivia, C., Barbieri, C., Gold, M. a., 2012. Between Forestry and Farming: Policy and Environmental Implications of the Barriers to Agroforestry Adoption. Can. J. Agric. Econ. 60, 155-175. doi:10.1111/j.1744-7976.2012.01248.x

Valdivieso-Pérez, I.A., García-Barrios, L.E., Álvarez-Solís, J.D., Nahed-Toral, J., 2012. From Cornfields to Grasslands: Change in the Quality of Soil. Terra Latinoam. 30, 363-374.

van der Werff, E., Steg, L., Keizer, K., 2013. It is a moral issue: The relationship between environmental self-identity, obligation-based intrinsic motivation and pro-environmental behaviour. Glob. Environ. Chang. 23, 1258-1265. doi:10.1016/j.gloenvcha.2013.07.018

Van Hecken, G., Bastiaensen, J., 2010. Payments for Ecosystem Services in Nicaragua: Do Marketbased Approaches Work? Dev. Change 41, 421-444. doi:10.1111/j.1467-7660.2010.01644.x 
Villamor, G.B., van Noordwijk, M., 2011. Social Role-Play Games Vs Individual Perceptions of Conservation and PES Agreements for Maintaining Rubber Agroforests in Jambi (Sumatra), Indonesia. Ecol. Soc. 16, 27.

Watts, S., Stenner, P., 2012. Doing Q Methodological Research: Theory, Method \& Interpretation. Sage Publications Ltd, London.

Wunder, S., 2006. Are direct payments for environmental services spelling doom for sustainable forest management in the tropics. Ecol. Soc. 11, 23.

Wünscher, T., Engel, S., 2012. International payments for biodiversity services: Review and evaluation of conservation targeting approaches. Biol. Conserv. 152, 222-230. doi:10.1016/j.biocon.2012.04.003

Zabala, A., 2015. Motivations and incentives for pro-environmental behaviour: the case of silvopasture adoption in the tropical forest frontier. University of Cambridge.

Zabala, A., 2014. qmethod: A package to explore human perspectives using Q methodology. R J. 6, 163:173.

Zabala, A., Pascual, U., 2016. Bootstrapping Q methodology to improve the understanding of human perspectives. PLoS One 11, e0148087. 


\section{Appendices}

Table A1: Original statements in Spanish. Key for topics: (A) importance of external payments in livelihoods; (B) environmental and conservation values; (C) personal attitudes towards work and livelihoods; (D) beliefs and preferences about cattle farming and land use; and (E) preferences and trade-offs between planting fodder trees and other livelihood activities, including perceptions about potential benefits of fodder trees.

\begin{tabular}{|c|c|c|c|}
\hline ID & Topic & Statement & Original statement in Spanish \\
\hline 1 & $\mathrm{C}$ & $\begin{array}{l}\text { My children and grandchildren will work the same } \\
\text { land that I cultivate now }\end{array}$ & $\begin{array}{l}\text { En las tierras que trabajo, trabajarán también mis } \\
\text { hijos y nietos }\end{array}$ \\
\hline 2 & $\mathrm{E}$ & $\begin{array}{l}\text { I prefer two hectares of pasture than one hectare of } \\
\text { fodder trees }\end{array}$ & $\begin{array}{l}\text { Prefiero } 2 \text { hectáreas de pasto de corte que } 1 \\
\text { hectárea de mataratón o guash }\end{array}$ \\
\hline 3 & $\mathrm{~A}$ & $\begin{array}{l}\text { The knowledge to earn more is what is of most } \\
\text { interest to me from external programmes. }\end{array}$ & $\begin{array}{l}\text { Lo que más me interesa de los programas es lo que } \\
\text { aprendo para ganar más dinero }\end{array}$ \\
\hline 4 & A & $\begin{array}{l}\text { I can maintain my family with my own work, } \\
\text { external payments are just an aid }\end{array}$ & $\begin{array}{l}\text { Puedo mantener a mi familia con mi propio trabajo. } \\
\text { Los subsidios sólo ayudan }\end{array}$ \\
\hline 5 & $\mathrm{E}$ & nes I receive more & $\begin{array}{l}\text { Con los programas de plantar árboles recibo más } \\
\text { dinero por mi trabajo }\end{array}$ \\
\hline 6 & $\mathrm{D}$ & s in cattle farming & $\begin{array}{l}\text { Podría obtener más ganancias de criar ganado sin } \\
\text { por ello estropear la tierra }\end{array}$ \\
\hline 7 & $\mathrm{E}$ & fodder trees involves a lot of effort and & $\begin{array}{l}\text { Sembrar basta } \\
\text { mucho esfuerz }\end{array}$ \\
\hline 8 & $\mathrm{~A}$ & in all external programmes that bring & Participo en $t$ \\
\hline 9 & $\mathrm{C}$ & convenient for me to cultivate my own & $\begin{array}{l}\text { Me co } \\
\text { compr }\end{array}$ \\
\hline 10 & B & th is responsibility of the & $\begin{array}{l}\text { ar el bosque es responsabilidad del dueño } \\
\text { no }\end{array}$ \\
\hline 11 & $\mathrm{C}$ & $\begin{array}{l}\text { I an } \\
\text { on } t\end{array}$ & $\begin{array}{l}\text { Hago las cuentas de lo que mejo } \\
\text { dedico a ello }\end{array}$ \\
\hline 12 & $\mathrm{D}$ & My & Mis terrenos $s$ \\
\hline 13 & $\mathrm{D}$ & $\begin{array}{l}\text { Bene } \\
\text { from }\end{array}$ & $\begin{array}{l}\text { Lo que da el ganado es } n \\
\text { la tierra }\end{array}$ \\
\hline 14 & $\mathrm{E}$ & o long for fodder & $\begin{array}{l}\text { ratón y el guash para for } \\
\text { ado en crecer }\end{array}$ \\
\hline 15 & A & hildren & $\begin{array}{l}\text { e den más subsidios para que mis } \\
\text { e ir a vivir a otro sitio }\end{array}$ \\
\hline 16 & $\mathrm{D}$ & $\begin{array}{l}\text { st money in } \\
\text { ng cows }\end{array}$ & $\begin{array}{l}\text { Me conviene } \\
\text { pasturas que e }\end{array}$ \\
\hline 17 & $\mathrm{E}$ & $\begin{array}{l}\text { A plant fodder trees } \\
\text { le }\end{array}$ & $\begin{array}{l}\text { lo, le sembraría mataratón o } \\
\text { umentar mis vacas }\end{array}$ \\
\hline 18 & $\mathrm{D}$ & native other than & $\begin{array}{l}\text { En secas no hay otro remedio que soltar las vacas al } \\
\text { monte }\end{array}$ \\
\hline 19 & $\mathrm{D}$ & $\begin{array}{l}\text { With more training I could improve very much my } \\
\text { work in cattle farming }\end{array}$ & $\begin{array}{l}\text { Con más capacitación, podría mejorar mucho mi } \\
\text { trabajo con el ganado }\end{array}$ \\
\hline 20 & $\mathrm{E}$ & $\begin{array}{l}\text { It is convenient to weed my fodder tree plot even if I } \\
\text { have other tasks, to produce more fodder. }\end{array}$ & $\begin{array}{l}\text { Me conviene deshierbar mi parcela de mataratón o } \\
\text { guash aunque tenga mucho trabajo, para tener más } \\
\text { forraje }\end{array}$ \\
\hline 21 & A & $\begin{array}{l}\text { If the government does not give me external } \\
\text { payments, taking care of the forest does not benefit } \\
\text { me }\end{array}$ & $\begin{array}{l}\text { Si el gobierno no me da subsidios, no me beneficia } \\
\text { cuidar el bosque }\end{array}$ \\
\hline 22 & $\mathrm{C}$ & I try new things in my job & Pruebo cosas nuevas en mi trabajo \\
\hline & A & $\begin{array}{l}\text { I would rather live by external payments than by } \\
\text { working my land. }\end{array}$ & $\begin{array}{l}\text { Prefiero vivir de los subsidios que del trabajo e } \\
\text { tierras }\end{array}$ \\
\hline
\end{tabular}


24 D I need to improve my pasture, otherwise cattle feed Necesito mejorar mis potreros porque si no se will run out in a few years acabará el alimento para mis vacas en unos años

25 B I can earn more as a cattle farmer if I let other wild Puedo ganar más como ganadero si dejo vivir a los animals live otros animales del bosque

26 E In order to dedicate one hectare to fodder trees Para excluir una hectárea de mataratón o guash por during two years, I would need more land dos años, necesitaría más terreno del que tengo

814

815 
Table A2: Factor loadings and flagged $Q$-sorts (indicated with stars)

\begin{tabular}{|c|c|c|c|c|c|c|}
\hline Respondent & \multicolumn{2}{|c|}{ 1. Self-sufficient } & \multicolumn{2}{|c|}{ 2. Environmentalist } & \multicolumn{2}{|c|}{ 3. Payment-dependent } \\
\hline 1 & -.16 & & -.12 & & .45 & $*$ \\
\hline 2 & -.11 & & .32 & & .39 & $*$ \\
\hline 3 & .10 & & .08 & & .58 & $*$ \\
\hline 4 & .23 & & .54 & $*$ & .36 & \\
\hline 5 & .64 & $*$ & .20 & & .18 & \\
\hline 6 & .12 & & .02 & & .70 & $*$ \\
\hline 7 & .50 & $*$ & -.04 & & .35 & \\
\hline 8 & .66 & $*$ & .19 & & .35 & \\
\hline 9 & .22 & & .52 & $*$ & .35 & \\
\hline 10 & .41 & & .30 & & .36 & \\
\hline 11 & .70 & $*$ & .28 & & .34 & \\
\hline 12 & .29 & & .29 & & .42 & $*$ \\
\hline 13 & .32 & & .14 & & .63 & $*$ \\
\hline 14 & .69 & $*$ & .08 & & -.02 & \\
\hline 15 & .60 & $*$ & .20 & & -.02 & \\
\hline 16 & .54 & $*$ & .25 & & .11 & \\
\hline 17 & .08 & & .24 & & .47 & $*$ \\
\hline 18 & .29 & & .60 & $*$ & -.03 & \\
\hline 19 & .52 & & .47 & & .24 & \\
\hline 20 & .15 & & .62 & $*$ & .13 & \\
\hline 21 & .43 & & .50 & $*$ & .25 & \\
\hline 22 & .30 & & .57 & $*$ & .07 & \\
\hline 23 & .59 & $*$ & .22 & & .06 & \\
\hline 24 & .35 & & .37 & & .37 & \\
\hline 25 & .49 & $*$ & .25 & & -.06 & \\
\hline 26 & .61 & $*$ & .44 & & .00 & \\
\hline 27 & .43 & & .45 & & .21 & \\
\hline 28 & .73 & $*$ & .23 & & .08 & \\
\hline 29 & .38 & & .67 & $*$ & .04 & \\
\hline 30 & .39 & $*$ & .14 & & .05 & \\
\hline 31 & .00 & & .60 & $*$ & .01 & \\
\hline 32 & .42 & $*$ & .34 & & .20 & \\
\hline
\end{tabular}

